\title{
HONOUR-AND HONOURS
}

$7 \mathrm{HE}$ exclusion of secular political questions from the subject matter of our Catholic Reviews, which obtained very largely before the war, was a weakness inherent in the mentality of the Catholic body at that time. It existed because Catholics, as a body, had never emerged from the atmosphere of sufferance; they felt their numerical weakness so strongly that it seemed a dangerous thing to discuss things on which they disagreed. It was a weakness because it hindered the development of political thought among Catholics, who, even if they have absorbed nothing more than the penny Catechism, are better equipped for it than those who have never had the advantage of that training in logic and philosophy. No Catholic should be capable of the mental confusion that so heavily overlays the political discussions of our secular press.

There is, and has been now for some time, every indication that this attitude of timid reserve has broken down. The Church in this country emerged from the war with a very much enhanced prestige, despite misrepresentation of the $\mathrm{Papal}$ neutrality. The historic Pastoral Letter of Cardinal Mercier made a deep and abiding impression on the non-Catholic mind. The returning troops brought back memories and impressions which scattered the mists of ignorant Victorian prejudice, and while the social teachings of Pope Leo XIII are slowly reaching the minds of the people, the striking Pastoral Letter of the Cardinal Archbishop of Westminster on social questions, and the courageous intervention of some of the bishops in particular matters, have given Catholics an opportunity and a 


\section{Blackfriars}

status which they have not had since Cardinal Manning settled the dock strike. Then they were admittedly not in a position to profit by it. But now the tide is beginning to return.

There is already a growing tendency to look for, and regard the attitude of Catholics to social questions. Largely it is in regard to matters of morals, and of doctrine, which still persist in the conscience of the common people. But no one who has come much in contact with Socialists for example, is unaware that it extends beyond any limited interpretation of these terms. In any case the field of morals is a very wide one, and it will not be difficult to show that the subject indicated in the title of this article comes within that field.

The social system of this country is not in itself a matter of morals or of doctrine, but the questions that have recently arisen regarding what may be called the maintenance and repair of the fabric of that social system are, and they have a peculiar interest for Catholics as distinct from any other body of opinion. For the Church alone, penetrating beyond the human frailties of rulers, whether princes or cabinet ministers, teaches that all authority comes from God, however unworthy the instrument, and it therefore follows that, of all people, Catholics are the more urgently concerned as to the honour and repute of those public men who are entrusted with the authority of the State; more especially in this country, where a system of popular election, however imperfect, renders them, if indifferent, acquiescent in any unworthy exercise of such a power.

In the present instance we have a charge preferred against the political rulers of the State. It is a charge that differs in degree according to the environment from which it proceeds. In the representative assemblies it amounts to no more than the condoning 


\section{Honour-and Honours}

of corruption in connection with the exercise of one of the prerogatives of their office. In other places, and in what some would call a freer atmosphere, the word 'condoning' is not heard, but more pungent phrases are. It is sufficient if, remembering the obligations of charity, we follow the minor count.

It is a singular feature of the debates that took place on the same evening in the two Houses of Parliament, that despite the sensational charges made in both Houses, the most interesting speeches-and in the deeper sense much the most startling speeches made, were those which put forward the Government's defence.

For consider the position. Charges have been made that honours and titles are corruptly bought and sold, for the benefit, primarily, of those political organizations which support those who bestow the honours and titles. That this is a grave matter of morals, few Catholics, at any rate, would dispute. And one would naturally expect that the reply to it would take the form either of a firm and strongly phrased denial of its truth, coupled with a demand for the most searching investigation; or else an admission that, on investigation, there had been found to be grounds for the charges, and that adequate punishment had been meted out to the guilty parties.

In fact, the reply did not remotely approach either of these forms.

In the Commons the Prime Minister advanced, at great length, the contention that these charges had been made before. 'I do not accept the statements made in previous debates in this House. I think they are wild; they have no basis in fact, and where there were mistakes I think they were exaggerated. I do not think therefore that the fact that on previous occasions you had exactly the same charges is a justification for an inquiry. A few well-advertised blunders 


\section{Blackfriars}

lead to a general inference being drawn. To draw that general inference was as unfair then as now, and is as unfair now as it was then.' This is the nearest we get to either denial or admission.

Later in his speech he said: 'There is no Prime Minister, either of to-day or in the past, who has any knowledge, when the names are submitted, as to who has contributed to the Party funds, or who has not. The mere fact that a man is rich is no proof that he has contributed. The Prime Minister has to judge on the record of public services as placed before him. Whoever is recommended, the Prime Minister ought not to have his judgment biassed by the knowledge of such a fact. I hope whatever the Committee of Inquiry decide they will stand by that-that the Prime Minister ought not to be informed as to whether any of the names before him are those of contributors to the Party fund.'

At about the same time, in the Lords, the Lord Chancellor said : 'if they recognised that party government had advantages which no alternative system could supply, then that which was necessary to maintain party government must be tolerated. Every noble Lord knew that no party could be maintained without a central fund. Where were those funds to come from? They certainly would not drop like the gentle rain from heaven ... He absolutely rejected the Marquess of Salisbury's view that the party subscription should be treated as an abs̀olutely irrelevent consideration. It never had been so treated, and such a system could not be carried out even by such a committee as Lord Salisbury proposed.'

Was it not Palmerston who remarked to his Cabinet : 'It doesn't much matter what we say, gentlemen, but for God's sake let us all say the same thing.' It is perhaps a small thing that two Ministers, both orators, should approach a subject from different 


\section{Honour-and Honours}

angles, and express divergent points of view. There is nothing unusual about it, and on any ordinary political question it might merely indicate a certain indiscreet, but still refreshing candour in one of the parties, giving expression to his own convictions instead of the convictions of the majority of his colleagues, by which he is bound. But in this present instance we have to bear in mind the antecedent circumstances. It is said that there is a traffic in honours, and that Party funds are bulging with the proceeds. The Prime Minister brushes aside these wild statements with the crushing revelation that no Prime Minister ever knows whether those he recommends for honours have contributed to the Party funds or not. He goes further, and asserts the principle that 'the Prime Minister ought not to have his judgment biassed by the knowledge of such a fact.' And he hopes that whatever else may befall, this principle will be maintained.

It is only rational to assume that when a Prime Minister condescends to enlighten us on the procedure of Prime Ministers, his revelations are authentic. So that the obvious, if unpleasant, construction that would follow a comparison of his speech with that of the Lord Chancellor may be ruled out. But a Lord Chancellor, in his turn, is by no means a negligible outsider. And if the first and most obvious construction to be placed on related facts is ruled out, then we must seek for another. It must be remembered that he was dealing with a very damaging attack, in the Upper House, where the Party machine is appreciably less powerful than it is in the Commons, since peers do not have to seek re-election. If he had known it, the exaggerated unworldliness of Prime Ministers would have been the strongest card he could play. The weakest, and the most unpopular, would be a cynical justification of the Party machine. It was the defence he chose to make. 


\section{Blackfriars}

The Lord Chancellor's knowledge of the habits of Prime Ministers may be slight, but his knowledge of the Party machine must be profound. And it does not require a very profound knowledge of it to see that the Prime Minister's revelation is likely to be very damaging to the Party funds. For if any of the new nobility have ever given money to those funds in the hope and expectation of reward they must feel now that it was obtained under false pretences. And although it will be nice for them to know that it was their high character, and not their cheque, which has been honoured, they are mostly business men, who usually very much dislike paying the full retail price for something they can get for nothing by simply sending round to a friend's warehouse.

It seems inevitable that as the Prime Minister's startling revelation sinks in there will be a slump. Because many of those who have in the past been the mainstay of the Party machines did undoubtedly hold very strongly to the view which the Lord Chancellor expressed, that "any leader of any party who believed in the doctrines which he and those associated with him were daily preaching, must count it a merit in those who assisted him to keep the party together when its fortunes were under a cloud, if that leader believed they were working for the preservation of the country and the empire.'

It may well be that the Lord Chancellor set himself to reassure this class of contributor, and that his challenging defence of the Party machine is intended to restore confidence. It must be remembered that the divergence between his speech and that of the Prime Minister is a divergence not of opinion but of fact. And the only theory which will satisfactorily cover both sets of facts is that the Prime Minister, like the Crown, has ceased to have any initiative in the bestowal of honours. 


\section{Honour-and Honours}

And this is the really grave and disturbing feature of this matter-the constant and convincing impression of powerful forces working behind the scenes. Why is it necessary to honour a man for contributing to the Party funds, and at the same time to conceal the fact of his contribution? Many men have given bountifully by stealth, laying up treasures in Heaven -but not in the House of Lords. That would be for them a disconcerting fate. They guard against it by not letting their right hand know what their left hand does. But these, one gathers, cover up their good deed with one hand, and hold out the other for the reward. The attitude is universally familiar. It is the attitude of bribery.

Ulic BuRKe. 